\title{
Isolation, partial purification and biochemical characterization of chloroplastic L-myo-inositol-1- phosphate synthase from a macro alga Enteromorpha intestinalis under high salinity
}

\author{
Sautrik Basu1*, Anusuya Basak², Rajashree Bose ${ }^{2}$, Rukmini Chakrabarty², Jukta Adhikari1,2 \\ ${ }^{1}$ Post Graduate Department of Botany, Barasat Govt. College, 10, K.N.C Road, Kolkata 700 124, India \\ ${ }^{2}$ Biochemistry Laboratory, Department of Botany, Presidency College (Currently Presidency University), 86/1 College Street, Kolkata \\ 700073 , India \\ *Corresponding author, E-mail: basusautrik@yahoo.co.in
}

\begin{abstract}
Induction of higher myo-inositol biosynthesis in a salinity driven macro-alga, Enteromorpha intestinalis (L.) Nees, as a model macrophyte, grown under natural conditions was established on the basis of a study on its prime enzyme, L-myo-inositol-1-phosphate synthase (MIPS) and the accumulation of free myo-inositol in chloroplasts. This enzyme was partially purified from isolated chloroplasts obtained from the plant grown under higher salinity to about 41-fold over homogenate following low-speed centrifugation, high-speed centrifugation, 0 to $80 \%$ ammonium sulfate precipitation, successive chromatography through DEAE-cellulose, Sephadex G-200 and BioGel $0.5 \mathrm{~m}$ columns. The apparent $\mathrm{M}_{\mathrm{r}}$ of the native enzyme was about $164 \mathrm{kDa}$. Temperature and $\mathrm{pH}$ optima were found to be $35^{\circ} \mathrm{C}$ and 7.5 respectively. D-glucose-6-phosphate and NAD were its exclusive substrate and coenzyme, respectively, with $K_{m}$ value $0.1761 \mathrm{mM}$ for D-glucsoe-6-phosphate and $0.1695 \mathrm{mM}$ for $\beta$-NAD as determined by non-linear regression kinetics method. Among the important monovalent and divalent cations tested, $\mathrm{K}^{+}$had trivial stimulatory effect while $\mathrm{Li}^{+}$was sturdily inhibitory. Divalent cations recorded variable effects. $\mathrm{Ca}^{2+}$ exhibited slight stimulatory effect and $\mathrm{Cd}^{2+}$ reduced MIPS activity faintly. Salts of $\mathrm{Cu}^{2+}$ and $\mathrm{Hg}^{2+}$ were found to be potent inhibitors of this enzyme. The concentration of free myo-inositol was found to increase proportionately with salinity at least up to 12 PSU.
\end{abstract}

Key words: chloroplast, Enteromorpha intestinalis, L-myo-inositol-1-phosphate synthase, marine macro alga, salinity Abbreviations: G-6-P, D-glucose-6-phosphate; I-1-P, L-myo-inositol-1-phosphate; ME, 2-mercaptoethanol; MIPS, L-myo-inositol-1phosphate synthase; PSU, practical salinity unit; ROS, reactive oxygen species; TLC, thin layer chromatography.

\section{Introduction}

Salinity is a rigorous abiotic stress restraining plant growth and development. In plants, salinity induces ion disparity, hyperosmotic stress, oxidative damage and other subsequent turbulences. Plants can ameliorate salinity stress by means of a large number of interlaced metabolic networks involving several compounds which either work synergistically or selectively (Majumder, Biswas 2006; Tuteja 2007). In order to combat salt stress plants have evolved a plethora of strategies, which include photosynthetic adjustment, salt-responsive signalling processes, ion exclusion, synthesis of compatible products, fortification of reactive oxygen species (ROS) scavenging mechanism, phytohormone regulation and cell structure modulation (Tuteja 2007). Salinity stress also has a marked effect on the accumulation of sugars and polyols (Gill et al. 2014). Sugar alcohols are a class of polyols that function as osmoprotectants/compatible solutes and also as ROS scavenging compounds (Shen et al. 1999; Ashraf, Foolard 2007). Among these polyols, mannitol and pinitol are considered as the prime ones related to salt stress in plants. Pinitol in particular is accumulated within the plant cell when it is under high salinity stress. The synthesis of pinitol in plants is dependent entirely on its precursor molecule myo-inositol, another indispensible sugar alcohol. It has been established previously that myo-inositol and its methylated derivatives is/are correlated with drought and/ or salinity tolerance (Bohnert et al. 1995).

Myo-inositol isomers and its derivatives have been reported to play several pivotal roles in metabolism of living organisms. Among these, 'salinity-driven' enhanced synthesis of this cyclitol has become an excellent area of research in recent years, even at the genetic level (Joshi et al. 2013). It has been reported earlier that some angiosperms when subjected to salinity stress by $\mathrm{NaCI}$ treatment exhibit remarkable salt tolerance, and this tolerance to high salinity conditions is often attributed to an enhanced 
activity of plastidial MIPS, which play a crucial role in the synthesis of osmoprotectants/osmolytes like inositols (Das-Chatterjee et al. 2006). Chloroplasts are imperative photosynthetic organelles, which are especially sensitive to salinity and existence of salt-responsive genes encoding for chloroplast-localized proteins, inclusive of those that bring about the synthesis of osmoprotectants like myoinositol, have been extensively reviewed very recently by Suo et al. (2017). L-myo-inositol-1-phosphate synthase (D-glucose-6-phosphate-1L-myo-inositol-1-phosphate synthase; MIPS; EC: 5.5.1.4) is the prime enzyme that catalyzes the irreversible conversion of D-glucose6-phosphate (G-6-P) to L-myo-inositol-1-phosphate (I-1-P/MIP), which is subsequently dephosphorylated by inositol monophosphatase (MIPP; EC: 3.1.3.25) to produce free myo-inositol. MIPP can dephosphorylate both L-MIP and D-MIP with equal efficiency (Eisenberg 1967). In plants, MIPS is present in two isoforms (cytosolic and chloroplastidial; Adhikari et al. 1987) and extensive perusal of available literature reveals that although several studies on MIPS have been carried out from various plants, animals and microorganisms, a vast majority of them have dealt exclusively with the cytosolic isoform (Loewus et al. 1978; Majumder, Biswas 2006). It is also noteworthy to mention here that the majority of the reports dealing with salt stress mitigation in plants (primarily phenerogams) are based on experiments where salinity conditions are simulated in the laboratory. Unfortunately, cryptogams, particularly algae, which occupy a lion share in any marine aquatic flora and exhibit many unknown eco-metabolic behaviours because of different life cycle patterns, have remained grossly neglected from such types of investigations.

Analyzing the above significant facts, the present investigation was aimed primarily towards understanding the probable eco-physiological correlation between the survival of marine macrophytes like Enteromorpha intestinalis growing under changeable salinity with the biosynthetic potential of plastidial myo-inositol. Although purification and characterization of chloroplast localized MIPS has been done by several investigators in a number of systems so far, no work involving a salinity tolerant algae has been conducted in any laboratory. To our knowledge this is the first report describing purification and characterization of salinity stressed chloroplastidial MIPS from a naturally grown algal source.

\section{Materials and methods}

\section{Plant material}

The experimental macro alga, Enteromorpha intestinalis (L.) Nees, was collected separately in two different seasons, i.e., rainy (salinity level is lower) and winter (salinity level is higher) seasons from Rambha, Chilika lagoon, Odisha, (geographic location: $19^{\circ} 50^{\prime} \mathrm{N}$ and $85^{\circ} 30^{\prime} \mathrm{E}$ ), India. The samples were kept frozen under $-20^{\circ} \mathrm{C}$ until use.

\section{MIP isolation}

Isolation of L-myo-inositol-1-phosphate synthase from different samples of $E$. intestinalis was carried out by homogenization of tissues in two volumes of the extraction buffer [50 mM Tris-acetate, pH 7.5 containing $0.2 \mathrm{mM}$ $\beta$-mercaptoethanol (ME)] followed by centrifugation at $1000 \mathrm{~g}$ for $5 \mathrm{~min}$ in a Remi C-24 BL cold centrifuge. Discarding the pellet, the supernatant fraction was collected. A portion of the supernatant at this state was kept separately under $0{ }^{\circ} \mathrm{C}$ (homogenate fraction). The remaining volume of the supernatant was centrifuged at $11400 \mathrm{~g}$ for $20 \mathrm{~min}$ (low-speed supernatant fraction). This preparation and also the previous were dialyzed separately, overnight, against $50 \mathrm{mM}$ Tris-acetate, $\mathrm{pH} 7.5$ containing $0.2 \mathrm{mM}$ ME. The dialyzed fractions were recovered from the respective dialysis bags and were used as the enzyme source(s) for the initial screening experiments.

\section{Isolation of chloroplasts}

Chloroplasts of E. intestinalis were isolated following the method of Hachtel (1976) with minor modifications as suggested by Adhikari et al. (1987). Green thalli of $E$. intestinalis (100 g, collected in winter season when marine water salinity remains higher) were washed several times with distilled water, allowed to drain off and placed in a plastic bag in refrigerator for few hours until they were turgid. Thereafter, all operations were carried out at 0 to $4{ }^{\circ} \mathrm{C}$. Tissues were homogenized in double volume of 20 $\mathrm{mM}$ Tris-acetate ( $\mathrm{pH}$ 7.0) containing $0.35 \mathrm{M}$ sucrose, $100 \mathrm{mM} \mathrm{MgCl}, 10 \mathrm{mM} \mathrm{KCl}, 1 \mathrm{mM} \mathrm{ME}, 10 \mathrm{mM}$ sodium ascorbate and centrifuged at $435 \mathrm{~g}$ for $5 \mathrm{~min}$ in a Remi C-24 BL cold centrifuge. The pellet was discarded and the supernatant was spun at $2850 \mathrm{~g}$ for $15 \mathrm{~min}$. The resultant chloroplast pellet was washed at least three times with the homogenizing medium. The final pellet was collected as chloroplasts and kept at $0{ }^{\circ} \mathrm{C}$ until further use. The authenticity of the isolated chloroplasts was established as described by Adhikari et al. (1987).

\section{Partial purification of chloroplastic MIPS}

Partial purification of chloroplastic MIPS from thalli of E. intestinalis was carried out at 0 to $4{ }^{\circ} \mathrm{C}$. Buffer-washed isolated chloroplasts obtained from $100 \mathrm{~g}$ of E. intestinalis thalli were homogenized in three volumes of a buffer (50 $\mathrm{mM}$ Tris-acetate, $\mathrm{pH}$ 7.0, containing $0.2 \mathrm{mM} \mathrm{ME}$; hitherto termed as standard buffer). The slurry was spun at 11400 $\mathrm{g}$ for $30 \mathrm{~min}$ and the supernatant was collected (low-speed supernatant). The resultant low-speed supernatant was then centrifuged at $104000 \mathrm{~g}$ in an ultracentrifuge (Hitachi GX Series, Model: CS 120G X 2 Micro Ultracentrifuge, Rotor No. 26) for $1 \mathrm{~h}$. The high-speed supernatant was then precipitated with ammonium sulfate $\left[\left(\mathrm{NH}_{4}\right)_{2} \mathrm{SO}_{4}\right]$ at the level of 0 to $80 \%$ saturation. The resultant $\left(\mathrm{NH}_{4}\right)_{2} \mathrm{SO}_{4}$ pellet was dissolved in minimal volume of standard buffer and dialyzed overnight against the same. Chromatography 
of the dialyzed fraction was done using an anion-exchange matrix DEAE-cellulose (obtained from GENEI, Bangalore, India) in a glass column $(1.2 \times 12 \mathrm{~cm})$. The effluent was collected and the column was washed with one bed volume of the standard buffer. The elution of the adsorbed proteins was made by a linear gradient of 0 to $0.5 \mathrm{M} \mathrm{KCl}$ prepared in standard buffer. The MIPS active DEAEcellulose fractions were pooled together and subsequent gel filtration was carried out through a Sephadex G-200 (obtained from Amersham Pharmacia Biotech, UK) column $(0.8 \times 14 \mathrm{~cm})$. The MIPS active Sephadex G-200 fractions were pooled together and again a different molecular sieve chromatography was performed through a BioGel A 0.5m (obtained from Bio-Rad, USA) column (0.8 $\times 10 \mathrm{~cm}$ ). The active MIPS BioGel A $0.5 \mathrm{~m}$ fractions were combined together and used as the enzyme preparation for biochemical characterization.

\section{Assay of L-myo-inositol-1-phosphate synthase}

Assay of L-myo-inositol-1-phosphate synthase was carried out by the procedure of Barnett et al. (1970) with slight modifications as per Adhikari et al. (1987). In a total volume of $500 \mu \mathrm{L}$ the incubation mixture contained $50 \mathrm{mM}$ Trisacetate, $\mathrm{pH} 7.5,14 \mathrm{mM} \mathrm{NH}_{4} \mathrm{Cl}, 8 \mathrm{mM} \mathrm{NAD}, 1 \mathrm{mM} \mathrm{ME}$, $50 \mathrm{mM} \mathrm{G}-6-\mathrm{P}$ and an appropriate protein aliquot (15 to $20 \mu \mathrm{g})$. The reaction was started by addition of substrate immediately after the addition of the enzyme with proper mixing. Duplicate tubes were run along with an appropriate blank (without enzyme) and a zero minute control in which $200 \mu \mathrm{L}$ of $20 \%$ chilled trichloracetic acid was added prior to the addition of the enzyme. The enzymatic incubation was carried out for $60 \mathrm{~min}$ at $37^{\circ} \mathrm{C}$. After $60 \mathrm{~min}$ the reaction was terminated by the addition of $200 \mu \mathrm{L}$ of $20 \%$ trichloracetic acid. Two such sets (set I with periodate and set II without periodate) were run simultaneously, each having one blank, one zero minute control and two experimental tubes. After completion of the enzyme incubation, the resultant supernatant was subjected to treatment with $700 \mu \mathrm{L}$ of $200 \mathrm{mM}$ sodium metaperiodate $\left(\mathrm{NaIO}_{4}\right)$ and incubated for $60 \mathrm{~min}$ at $37^{\circ} \mathrm{C}$. Then, $1.4 \mathrm{~mL}$ of $1 \mathrm{M} \mathrm{Na}_{2} \mathrm{SO}_{3}$ (prepared immediately before use) was added in case of set I to destroy excess $\mathrm{NaIO}_{4}$. In set II, distilled $\mathrm{H}_{2} \mathrm{O}$ was added instead of $\mathrm{NaIO}_{4}$ and $\mathrm{Na}_{2} \mathrm{SO}_{3}$ to maintain the volume equal with the set I. Inorganic phosphate was liberated from myo-inositol-1-phosphate during oxidation. Cleavage of G-6-P also took place but it was thought to be extremely low (2 mmol of Pi per mol of G-6-P), which could be subtracted considering the blank or zero minute control from the experimental value in set I. Hydrolysis of phosphate from G-6-P by contaminating phosphatase (if any) was measured by subtracting the value of the blank or zero minute control from the experimental value in set II. Product specific cleavage of inorganic phosphate was estimated by subtracting the corrected value of set II from that of set I. Inorganic phosphate was estimated by the method of Chen et al. (1956). Protein was determined according to the method of Bradford (1976) with bovine serum albumin as a standard.

Polyacrylamide gel electrophoresis of MIPS under non-dissociating condition was performed following the methods of Bollag et al. (1996) with minor modifications.

\section{Characterization of chloroplastidial MIPS}

All characterization experiments were carried out using partially purified chloroplastidial MIPS (active BioGel A $0.5 \mathrm{~m}$ fraction) isolated from E. intestinalis collected in winter season only.

\section{Determination of temperature, $\mathrm{pH}$, glucose-6-phosphate and NAD optima}

The temperature sensitivity of the plastidial MIPS reaction was investigated at a temperature range of 0 to $60^{\circ} \mathrm{C}$ with intervals of $5{ }^{\circ} \mathrm{C}$ to determine its optima. Partially purified MIPS were incubated at different temperatures using separate experimental sets within a multi thermo incubator (Eyela, Japan) in presence of all the standard assay components for one hour. Thereafter, the subsequent steps of enzyme assay in all sets were completed as described in the MIPS assay procedure.

The $\mathrm{pH}$ sensitivity of the plastidial MIPS reaction was studied in partially purified plastidial MIPS assay to determine the optima, using variable $\mathrm{pH}$ (5.0 to 9.0, in increments of 0.5 ) of the buffer (50 mM Tris-acetate) in different experimental sets keeping other assay components unaltered.

To determine substrate concentration (G-6-P) optima for MIPS, partially purified plastidial MIPS assay was carried out using variable G-6-P (substrate) concentrations (without changing other standard assay ingredients) in the range of 0.0 to $10 \mathrm{mM}$ at an interval of $1.0 \mathrm{mM}$ in separate experimental sets following standard assay method as described earlier for all experimental sets.

To determine coenzyme concentration (NAD) optima for MIPS, partially purified plastidial MIPS assay was carried out using variable NAD (coenzyme) concentrations (without changing other standard assay ingredients) in the range of 0.0 to $1.0 \mathrm{mM}$ at an interval of $0.1 \mathrm{mM}$ in separate experimental sets following standard assay method as described earlier for all experimental sets.

\section{Molecular weight determination}

Approximate molecular weight of the native MIPS was determined by gel-filtration through Sephadex G-200 matrix. The Sephadex G-200 was suspended in $50 \mathrm{mM}$ Trisacetate ( $\mathrm{pH} 7.5)$ and packed in a column of suitable size and calibrated with $1 \mathrm{~mL}$ each of marker proteins e.g., catalase $(221.6 \mathrm{kDa})$; bovine serum albumin dimer $(133.352 \mathrm{kDa})$; phosphorylase-b $(97.4 \mathrm{kDa})$; ovalbumin $(43 \mathrm{kDa})$, carbonic anhydrase $(29 \mathrm{kDa})$ and lysozyme $(14.3 \mathrm{kDa})$. The void volume was determined with blue dextran 2000 (1 mg per 
$\mathrm{mL})$. All standards were loaded in the column separately and fractions $(0.75 \mathrm{~mL})$ were collected at a flow rate of 0.75 $\mathrm{mL}$ per $6 \mathrm{~min}$. Each individual protein peak was located by spectrophotometric scanning at $280 \mathrm{~nm}$ in a Jasco V-5 UVVIS Spectrophotometer. A standard curve was prepared by plotting relative elution volume of proteins against their respective log molecular weights.

\section{Kinetic analysis}

Evaluation of the kinetic parameters of MIPS, namely, the Michaelis-Menten constant $\left(K_{m}\right)$ and the maximum rate $\left(V_{m}\right)$ were analyzed. In order to establish relations between the substrate (G-6-P) and coenzyme (NAD) levels and the rate of the enzyme catalyzed reaction, the parameters $K_{m}$, $V_{m}$, and the catalytic efficiency $\left(V_{m} / K_{m}\right)$ were calculated by non-linear regression kinetics method using the software Prism 5 (Graph Pad).

\section{Isolation and quantification of free myo-inositol}

Free myo-inositol was isolated by the method of Charalampous, Chen (1966) with minor modifications. Plant tissue $(1 \mathrm{~g})$ was homogenized in double volumes of $0.15 \mathrm{M} \mathrm{KCl}$ in a homogenizer for 2 to $3 \mathrm{~min}$. The crude homogenate was centrifuged at $8500 \mathrm{~g}$ for $20 \mathrm{~min}$. The supernatant was collected and deproteinized by boiling in a water bath for $10 \mathrm{~min}$. Then it was cooled and again centrifuged at $8500 \mathrm{~g}$ for $30 \mathrm{~min}$ in a Remi C-24 BL cold centrifuge and the supernatant was collected. The resultant supernatant was demineralized by passing through a mixed bed column $0.3 \times 1.5 \mathrm{~cm}$ each of Dowex-1-Cl(100 to 200 mesh) and Amberlite IR- $120^{+}$(sodium form) (both obtained from HiMedia Laboratories Ltd., Mumbai, India). The Dowex was placed on top of the Amberlite and the demineralised solution was collected as effluent. The solution was concentrated to $100 \mu \mathrm{L}$ by evaporating in a water bath and treated with $100 \mu \mathrm{L}$ of $0.15 \mathrm{M} \mathrm{Ba}(\mathrm{OH})_{2}$ solution at $100{ }^{\circ} \mathrm{C}$ for $15 \mathrm{~min}$. The mixture was again demineralized through another column of the same composition after dilution with $1.3 \mathrm{~mL}$ of water. Then, the volume of the above demineralized solution was reduced to $1.0 \mathrm{~mL}$ by heating in a water bath and treated with equal volume of $80 \%$ ethanol at $4{ }^{\circ} \mathrm{C}$ to remove starch (if any).

The filtrate was collected by low speed centrifugation and the volume was reduced to dryness by boiling in a water bath. The content was carefully washed and dissolved in $200 \mu \mathrm{L}$ of water. From this solution myo-inositol and sugars were separated by one-dimensional ascending thin layer chromatography (TLC). From about $200 \mu \mathrm{L}$ of the above solution, $50 \mu \mathrm{L}$ was spotted on a TLC plate (E. Merck, Germany) containing another spot of marker myo-inositol ( $50 \mu \mathrm{g}$ in $50 \mu \mathrm{L}$ of $\mathrm{H}_{2} \mathrm{O}$ ). The chromatography was carried out at room temperature for 3 to $4 \mathrm{~h}$ using acetone/water $(85: 15, \mathrm{v} / \mathrm{v})$ as the mobile phase. On completion of the run, the TLC plate was taken out from the chamber and dried. A narrow strip of the plate with marker inositol was cut out and stained according to the method of Trevelyan et al. (1950). The plate was dipped into solution I $(0.1 \mathrm{~mL}$ saturated aqueous solution of $\mathrm{AgNO}_{3}$ in $100 \mathrm{~mL}$ of acetone) for about $1 \mathrm{~min}$, dried quickly and dipped into solution II [0.5 $\mathrm{N} \mathrm{NaOH}$ solution prepared in 5\% ethanol] for coloration. The background colour was eliminated by dipping the dried strip into solution III $\left(5 \% \mathrm{Na}_{2} \mathrm{~S}_{2} \mathrm{O}_{3}\right)$. Thus, the inositol area became distinct by this stain. From the unstained chromatogram, the TLC strip corresponding to the inositol position was scraped out and mixed with $\mathrm{H}_{2} \mathrm{O}$, kept overnight under refrigeration, the solution was collected by means of low-speed centrifugation and the content of free myo-inositol was estimated spectrophotometrically.

Spectrophotometric estimation of free myo-inositol was carried out according to the method of Gaitonde and Griffiths (1966) in which myo-inositol was oxidized by sodium meta-periodate and the micro quantity of myoinositol was determined from the decrease of the quantity of sodium meta-periodate in the reaction mixture after oxidation.

To about $1 \mathrm{~mL}$ of solution containing free myo-inositol isolated by the method describes earlier, $1 \mathrm{~mL}$ of $5 \mathrm{mM}$ $\mathrm{NaIO}_{4}$ was added and incubated at $37^{\circ} \mathrm{C}$ for $2 \mathrm{~h}$. Then, 200 $\mu \mathrm{L}$ aliquot of the reaction mixture was taken in a stoppered tube and $8.0 \mathrm{~mL}$ of $0.1 \mathrm{M}$ borate buffer $(\mathrm{pH} 8.1)$ was added to it followed by the addition of $2.0 \mathrm{~mL}$ of freshly prepared $2 \%$ potassium iodide solution. The solution was mixed thoroughly and the extinction was measured at 355 $\mathrm{nm}$ in a Systronics-106 spectrophotometer after $5 \mathrm{~min}$ of incubation. The periodate remaining after the oxidation of myo-inositol was estimated by subtracting the extinction of the sample from that of the reagent blank prepared with 1.0 $\mathrm{mL}$ of water. myo-Inositol concentration was determined by extrapolation from a standard curve that was prepared using known concentrations of myo-inositol (0 to $100 \mu \mathrm{g})$.

\section{Determination of salinity}

Salinity of water, collected from Chilika lagoon (in separate sterile containers) in rainy and winter seasons was measured using Systronics Water Analyzer (Model No. 571) in the collection spots.

\section{Results}

\section{Identification of chloroplastic MIPS and free myo-inositol under variable salinity}

In the present investigation appreciable activity of the chloroplastidial MIPS was obtained from the thalli of $E$. intestinalis collected from Chilika lagoon in both rainy (plants grown under naturally lower salinity; PSU 8.10 \pm 0.53 ) and winter (plants grown under naturally higher salinity; PSU $12.23 \pm 0.61$ ) seasons (Table 1). Interestingly, higher activities of MIPS as well as the elevated content of free $m y o$-inositol were detected in thalli grown in winter season than in the samples from the rainy season (Table 1). 
Table 1. Activity of myo-inositol-1-phosphate synthase and free myo-inositol concentration in the thalli of Enteromorpha intestinalis grown under different salinity conditions

\begin{tabular}{|c|c|c|c|c|c|}
\hline Experimental sample & $\begin{array}{c}\text { Salinity of } \\
\text { water (PSU) }\end{array}$ & $\begin{array}{l}\text { Free myo-inositol } \\
\text { concentration (mg } \\
\left.\qquad \mathrm{g}^{-1} \mathrm{FW}\right)\end{array}$ & $\begin{array}{l}\text { Specific activity of } \\
\text { MIPS [nmol I-1-P } \\
\text { produced } \mathrm{mg}^{-1} \\
\text { protein } \mathrm{h}^{-1} \text { ) }\end{array}$ & Enzyme source & $\begin{array}{l}\text { Total protein } \\
\left(\mathrm{mg} \mathrm{g}^{-1} \mathrm{FW}\right)\end{array}$ \\
\hline \multirow{2}{*}{$\begin{array}{l}\text { S-1 (sample collected in } \\
\text { rainy season) }\end{array}$} & $8.10 \pm 0.53$ & $1.34 \pm 0.27$ & $185.0 \pm 23.90$ & Homogenate fraction & 2.216 \\
\hline & & & & $\begin{array}{c}\text { Low-speed } \\
\text { supernatant fraction }\end{array}$ & 1.985 \\
\hline \multirow{2}{*}{$\begin{array}{l}\text { S-2 (sample collected in } \\
\text { winter season) }\end{array}$} & $12.23 \pm 0.61$ & $4.16 \pm 0.77$ & $341.0 \pm 42.18$ & Homogenate fraction & 2.418 \\
\hline & & & & $\begin{array}{c}\text { Low-speed } \\
\text { supernatant fraction }\end{array}$ & 1.853 \\
\hline
\end{tabular}

\section{Partial purification and characterization of chloroplastic MIPS}

The present work describes an efficient protocol for partial purification of chloroplastidial MIPS from the thalli of E. intestinalis by low speed centrifugation, high speed centrifugation, ammonium sulfate precipitation and chromatography on DEAE cellulose, Sephadex G-200 and Biogel-A 0.5m (Fig. 1A, B, C). The overall purification of plastidial MIPS was recorded to be around 41-fold with about $13 \%$ yield (Table 2). The native PAGE profile of the partially purified MIPS protein is shown in Fig. 2 along with the corresponding enzyme activity.

The apparent molecular weight $\left(\mathrm{M}_{\mathrm{r}}\right)$ of the native plastidial enzyme was determined by gel filtration on a Sephadex G-200 column. The molecular mass was recorded to be about $164 \mathrm{kDa}$. MIPS from E. intestinalis recorded maximum activity when assayed in presence of $50 \mathrm{mM}$ Tris-acetate buffer (pH-7.5), $14 \mathrm{mM} \mathrm{NH} \mathrm{m}_{4} \mathrm{CI}, 0.8 \mathrm{mM}$ $\mathrm{NAD}^{+}, 0.5 \mathrm{mM} \mathrm{ME}$ and $5 \mathrm{mM}$ G-6-P. About $24 \%$ activity was lost when Tris buffer was omitted from the reaction mixture. Elimination of $\mathrm{NAD}^{+}$resulted in complete loss of enzymatic activity, while removal of $\mathrm{NH}_{4} \mathrm{Cl}$ and $\mathrm{ME}$ resulted in the loss of MIPS activity by about 38 and $9 \%$ respectively (Table 3 ). In the experimental algal MIPS, D-glucose-6-phosphate (G-6-P) has been found to be the exclusive substrate for the production of L-myoinositol-1-phosphate (MIP). Other hexose and pentose phosphates viz. D-galactose-6-phosphate, D-mannose6-phosphate, D-fructose-6-phosphate, D-ribose-5phosphate, D-glucose-1, 6-bisphosphate and D-fructose-1, 6-bisphosphate under identical concentrations (5 mM) replacing G-6-P were ineffective as substrate (Table 4). It was further revealed that $\mathrm{NAD}^{+}$acted as the sole coenzyme for this plastidial MIPS. It could not be replaced by NADP, FAD or FADP (Table 5).

The thermal sensitivity of the MIPS reaction was investigated in a temperature range of 0 to $60{ }^{\circ} \mathrm{C}$ with intervals of $5{ }^{\circ} \mathrm{C}$ (Fig. 3A). Minimum activity of MIPS was recorded at 10 and $50^{\circ} \mathrm{C}$ respectively. However, the enzyme was remarkably active between the temperature ranges of 20 to $40{ }^{\circ} \mathrm{C}$ with a maxima at $35^{\circ} \mathrm{C}$ (Fig. $3 \mathrm{~A}$ ). The enzyme
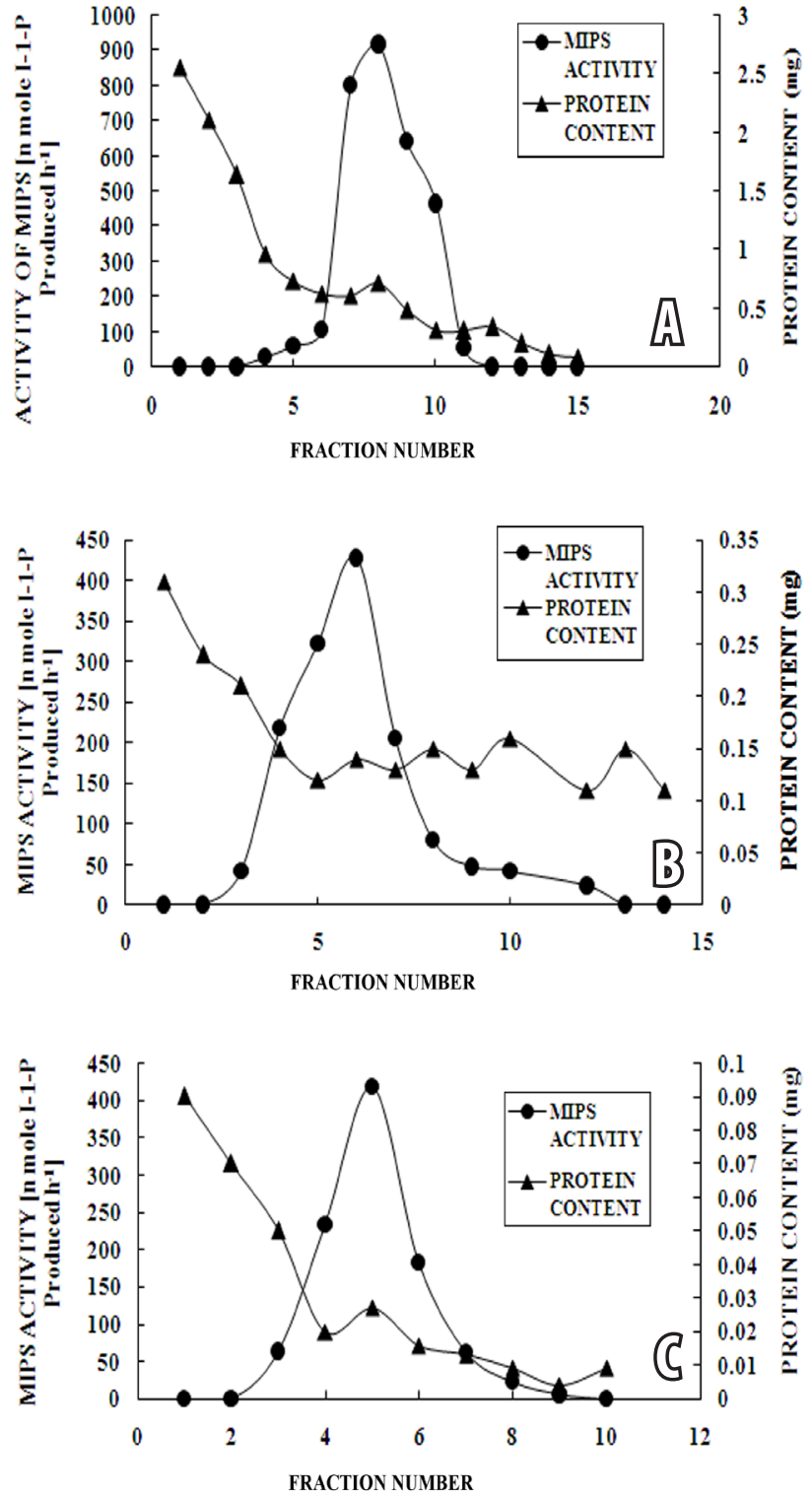

Fig. 1. Typical elution profiles of Enteromorpha intestinalis (winter sample) plastidial MIPS and proteins chromatographed through different columns: DEAE cellulose (A), Sephadex G-200 (B) and Biogel A-0.5m (C). 
Table 2. Partial purification of L-myo-inositol-1-phosphate synthase from isolated chloroplasts of Enteromorpha intestinalis (winter sample). Results are mean \pm SE (in the parenthesis) of three replicates

\begin{tabular}{|lccccc}
\hline Fraction & Total protein $(\mathbf{m g})$ & $\begin{array}{c}\text { Specific activity } \\
(\text { nmol I-1-P } \\
\text { produced } \mathbf{~ m g}^{-1} \\
\left.\text { protein } \mathbf{h}^{-1}\right)\end{array}$ & $\begin{array}{c}\text { Total activity } \\
(\text { nmol I-1-P } \\
\left.\text { produced } \mathbf{~}^{-1}\right)\end{array}$ & Yield (\%) & Fold purification \\
\hline Homogenate & $19.776(2.114)$ & $320.00(16.71)$ & $6328.32(31.92)$ & $100.00(13.23)$ & $1.00(0.17)$ \\
\hline $11400 \times$ g supernatant & $15.895(0.172)$ & $324.73(8.47)$ & $5161.58(34.05)$ & $81.56(11.29)$ & $1.01(0.14)$ \\
\hline $104000 \times$ g supernatant & $15.078(0.156)$ & $326.06(6.46)$ & $4916.33(26.73)$ & $77.68(11.24)$ & $1.01(0.12)$ \\
\hline to $80 \%\left(\mathrm{NH}_{4}\right)_{2} \mathrm{SO}_{4}$ & $12.056(0.094)$ & $335.84(7.11)$ & $4048.88(22.81)$ & $63.97(10.04)$ & $1.04(0.18)$ \\
\hline DEAE-cellulose & $2.146(0.047)$ & $1483.95(23.16)$ & $3184.55(33.57)$ & $50.32(6.80)$ & $4.63(1.42)$ \\
\hline Sephadex G-200 & $0.309(0.016)$ & $3806.08(18.69)$ & $1176.07(27.32)$ & $18.58(3.72)$ & $11.89(2.08)$ \\
\hline BioGel A 0.5m & $0.064(0.004)$ & $13068.45(145.76)$ & $836.38(48.11)$ & $13.21(1.94)$ & $40.83(2.84)$ \\
\hline
\end{tabular}

was most active within a $\mathrm{pH}$ range of 7.0 to 7.5 with $\mathrm{pH}$ optima of 7.5 (Fig. 3B).

Effect of different mono valent and divalent cations was tested in the range of 1 to $10 \mathrm{mM}$ concentrations with chloride anions of the respective metals. Among the monovalent cations tested $\mathrm{K}^{+}$had trivial stimulatory effect, $\mathrm{Na}^{+}$played an impartial role, and $\mathrm{Li}^{+}$was sturdily inhibitory (38 to $70 \%$ inhibition). Using the analogous concentrations of divalent cations it was revealed that $\mathrm{Ca}^{2+}$ exhibited no effect, $\mathrm{Cd}^{2+}$ exhibited minor inhibitory effect (2 to $10 \%$ inhibition) while $\mathrm{Hg}^{2+}$ strongly inhibited the enzyme activity (Fig. 4).

Kinetic analysis was carried out using G-6-P in the range of 0 to $10 \mathrm{mM}$, at an interval of $1.0 \mathrm{mM}$. The reaction rate was noted to increase with respect to G-6-P concentration of 3.0 to $4.0 \mathrm{mM}$. Using non-linear regression kinetics the
$\mathrm{K}_{\mathrm{m}}$ and $\mathrm{V}_{\mathrm{m}}$ values for G-6-P were determined to be 1.1761 $\mathrm{mM}$ and $3.926 \mu \mathrm{M}$, respectively (Fig. 3C). On the other hand the $\mathrm{K}_{\mathrm{m}}$ and $\mathrm{V}_{\mathrm{m}}$ values for the coenzyme NAD were calculated to be $0.1695 \mathrm{mM}$ and $4.48 \mu \mathrm{M}$, respectively (Fig. 3D).

\section{Discussion}

Chilika lagoon (a brackish water lagoon, covering an area of over $1100 \mathrm{~km}^{2}$ ), proximate to the Bay of Bengal, India is a large repository of plants belonging to different phylogenetic groups. Algae comprise the predominating flora from the cryptogamic group at Chilika. The lagoon undergoes a cyclical variation in salinity throughout the year and the salinity level has been found to decrease from June and attains its minimum in September; the

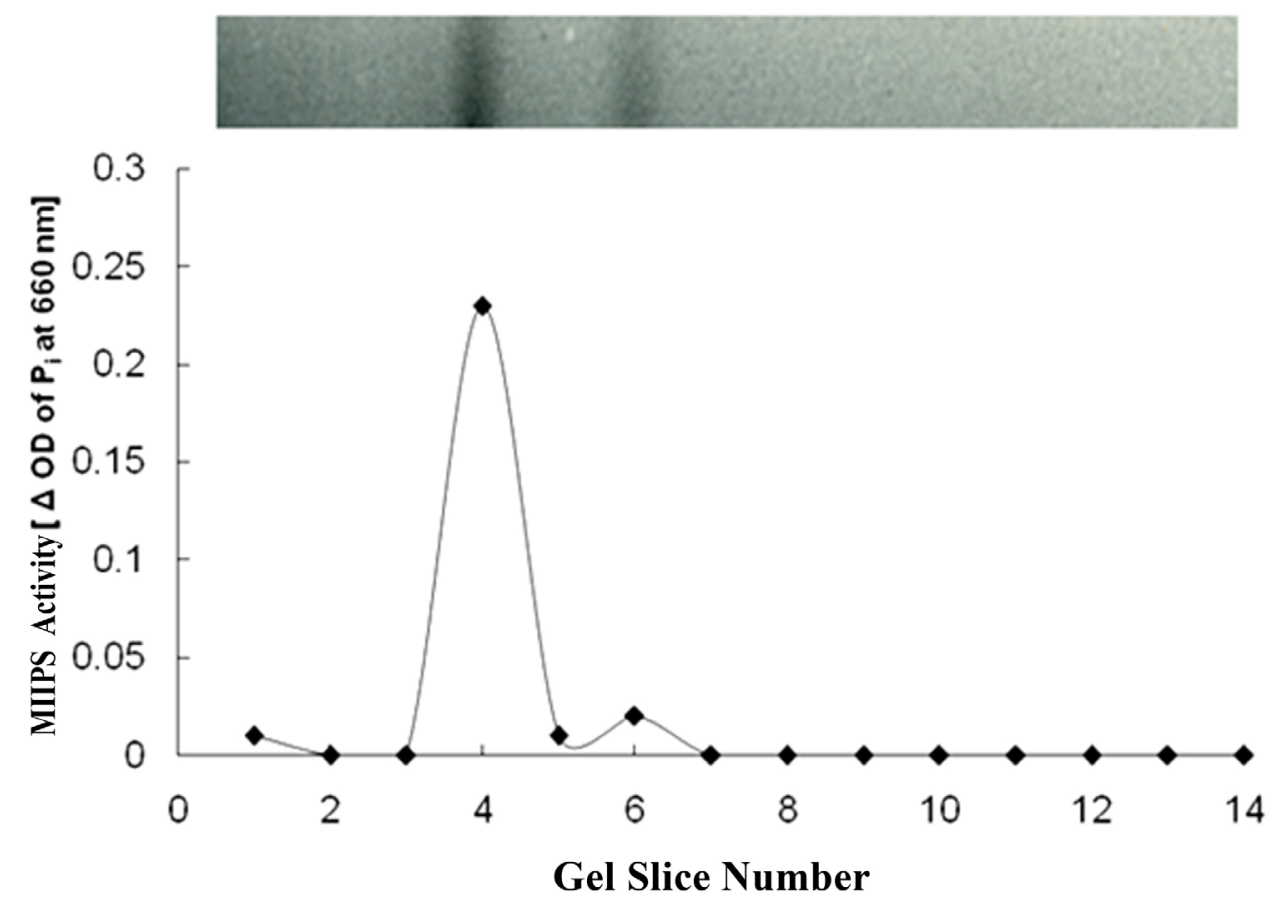

Fig. 2. Native PAGE profile of Enteromorpha intestinalis showing the MIPS activity of the corresponding protein band. 
Table 3. Effect of different assay components on chloroplastidial MIPS activity in Enteromorpha intestinalis (winter sample). Values are means $\pm \mathrm{SE}, \mathrm{n}=3$. Specific activity is defined as nmole I-1-P produced $\mathrm{mg}^{-1}$ protein $\mathrm{h}^{-1}$

\begin{tabular}{lc} 
Assay component & $\begin{array}{c}\text { Chloroplastidial } \\
\text { MIPS } \\
\text { activity }\end{array}$ \\
Complete set (control) & $12764 \pm 188$ \\
\hline Without substrate (G-6-P) & 0.00 \\
Without buffer & $9674 \pm 170$ \\
Without $\mathrm{NAD}^{+}$ & 0.00 \\
\hline Without $\mathrm{NH}_{4} \mathrm{Cl}$ & $7885 \pm 107$ \\
Without $\mathrm{ME}$ & $11663 \pm 129$
\end{tabular}

level increases gradually during winter months. It has been reported earlier that salinity plays a crucial role in coastal lagoons like Chilika, as the distribution of flora and fauna is influenced greatly by fluctuations in salinity levels (Rath, Adhikary 2005). However, it must be taken into account that higher salinity levels severely impairs metabolism in plants by imposing osmotic stress and loss of turgor.

The results obtained in the present investigation clearly show a correlation between plastidial myoinositol metabolism and salinity stress. Table 1 depicts appreciable activity of MIPS, both in homogenate and in low-speed supernatant fractions. However, the titre of the enzyme protein in the homogenate fraction was higher in comparison to the low speed supernatant fraction, specifically in case of the more salt-stressed sample. Analyzing the results depicted in Table 1, it appears that the enzyme remains functional in all the preparations at least with a basal activity and this observation also strongly suggest possible existence of multi molecular forms of this enzyme in the Enteromorpha system, where at least, one form may be membrane bound or in a broader sense, particulate. This is in complete agreement with the results obtained by previous workers (Adhikari et al. 1987; Ray Chaudhuri et al. 1996). The results obtained in the present investigation clearly show that even a non-vascular plant like $E$. intestinalis support the salt-induced enhancement of MIPS as reported earlier in higher plants by Ray Chaudhuri et al. (1997). Taking these facts into consideration subsequent studies were carried out using the winter grown thalli of E. intestinalis.

The plastidial MIPS was purified around 41-fold with about $13 \%$ yield (Table 2 ) and the apparent molecular mass $\left(\mathrm{M}_{\mathrm{r}}\right)$ was recorded to be about $164 \mathrm{kDa}$. The molecular mass of the native plastidial MIPS has been found to vary in between $155 \mathrm{kDa}$ in Diplopterygium glaucum and $180 \mathrm{kDa}$ in Entamoeba histolytica as reported by Chettri et al. (2006a) and Lohia et al. (1999) respectively; while the molecular mass of the native cytosolic isoform has been found to vary in between 179 to $200 \mathrm{kDa}$ (Ray Chaudhuri et al. 1997). Since the enzyme did not exhibit any activity in absence of
Table 4. Substrate specificity on MIPS activity in chloroplastidial Enteromorpha intestinalis (winter sample). Values are means $\pm \mathrm{SE}$, $\mathrm{n}=3$. Specific activity is defined as nmole I-1-P produced $\mathrm{mg}^{-1}$ protein $\mathrm{h}^{-1}$

\begin{tabular}{lcc} 
Substrate & $\begin{array}{c}\text { Concentration } \\
(\mathbf{m M})\end{array}$ & MIPS activity \\
\hline D-glucose-6-phosphate & 5.00 & $12685 \pm 207$ \\
\hline D-galactose-6-phosphate & 5.00 & 0.00 \\
D-mannose-6-phosphate & 5.00 & 0.00 \\
\hline D-fructose-6-phosphate & 5.00 & 0.00 \\
\hline D-ribose-5-phosphate & 5.00 & 0.00 \\
D-glucose-1,6-bisphosphate & 5.00 & 0.00 \\
D-fructose-1,6-bisphosphate & 5.00 & 0.00
\end{tabular}

Table 5. Coenzyme specificity of MIPS from the chloroplastidial MIPS preparations from Enteromorpha intestinalis (winter sample). Values are means $\pm S E, n=3$. Specific activity is defined as nmole I-1-P produced $\mathrm{mg}^{-1}$ protein $\mathrm{h}^{-1}$

\begin{tabular}{|lcc|}
\hline Coenzyme & Concentration $(\mathbf{m M})$ & $\begin{array}{c}\text { Specific MIPS } \\
\text { activity }\end{array}$ \\
\hline NAD & 1.0 & $12836 \pm 107$ \\
\hline NADP & 1.0 & 0.00 \\
FAD & 1.0 & 0.00 \\
FADP & 1.0 & 0.00 \\
\hline
\end{tabular}

$\mathrm{NAD}^{+}$, it can be safely concluded that the plastidial MIPS from E. intestinalis did not possess any 'built in' $\mathrm{NAD}^{+}$in its molecular architecture, unlike the MIPS obtained from mammalian adult brain (Adhikari, Majumder 1983) and from Euglena gracilis (Dasgupta et al. 1984). Our results are however in complete agreement with the reports published earlier (Chettri et al. 2006a; 2006b; Basak et al. 2012). The plastidial MIPS exhibited a temperature optima of $35^{\circ} \mathrm{C}$, which is also in complete congruence with majority of the published reports sans a few where a lower temperature maxima for MIPS has been recorded (Chettri et al. 2005; 2006a; 2009). This may be attributed to the variation in the habitat of the experimental sample(s). The enzyme was most active within a $\mathrm{pH}$ range of 7.0 to 7.5 with $\mathrm{pH}$ optima of 7.5, like reported for other sources (Maeda, Eisenberg 1980; Donahue, Henry 1981a; 1981b; Dasgupta et al. 1984; Chettri et al. 2006a).

Among the monovalent cations tested $\mathrm{K}^{+}$had trivial stimulatory effect, $\mathrm{Na}^{+}$played an impartial role and $\mathrm{Li}^{+}$was sturdily inhibitory to this enzyme. Similar characteristic features have been observed in rat testis enzymes and also from several plant sources (Basak et al. 2012). $\mathrm{Na}^{+}$, in contrast, has been found to exhibit a placid inhibitory effect in pteridophytes as reported earlier by Chettri et al. (2005; 2006a; 2006b).

The results obtained in the present investigation therefore establish a clear correlation between myo-inositol 

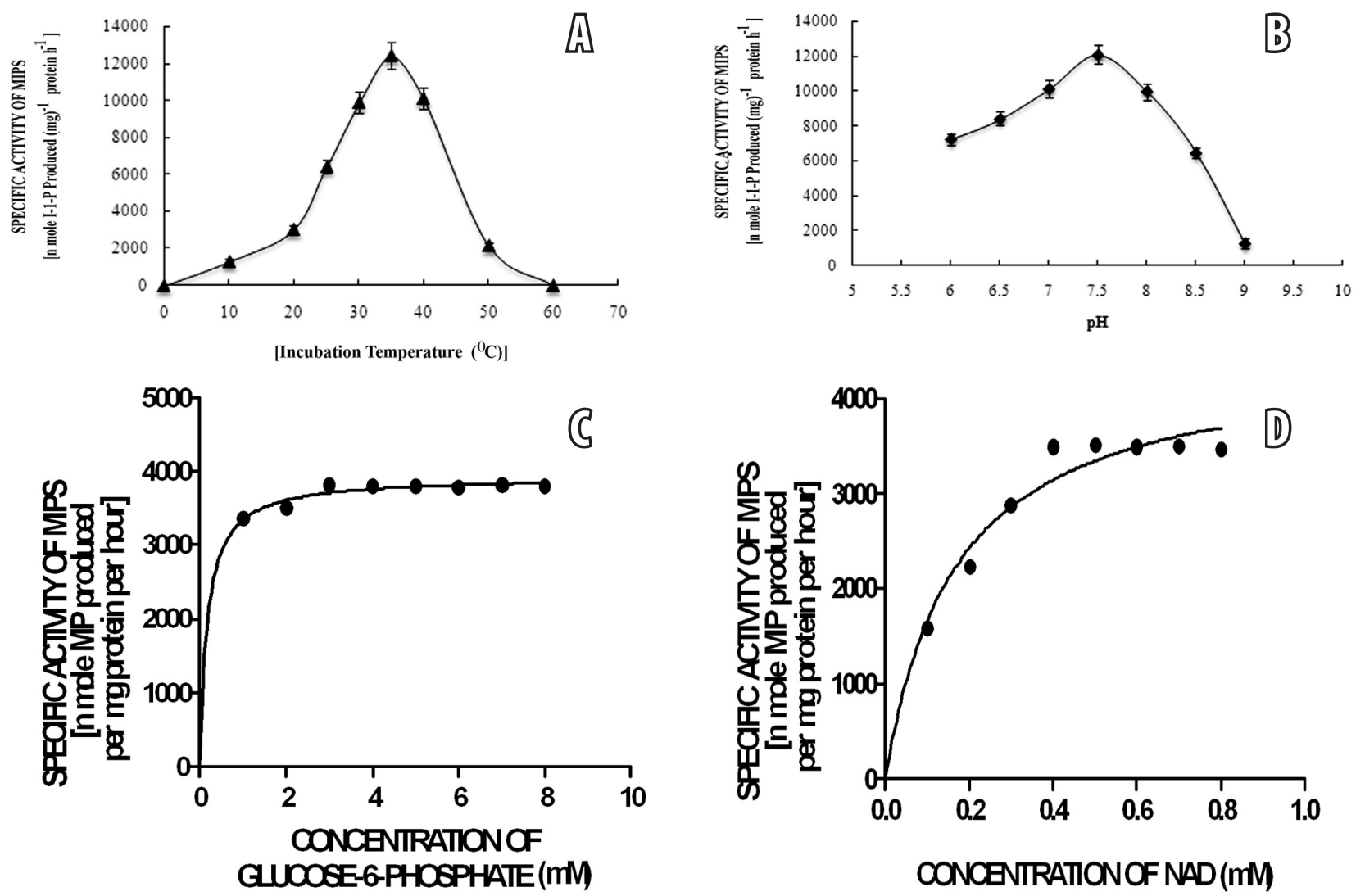

Fig. 3. A, effect of incubation temperature on Enteromorpha intestinalis (winter sample) chloroplastidial MIPS activity. Activity is expressed as nmol 1-1-P produced per mg protein per h. B, pH dependence of chloroplastidial MIPS of E. intestinalis (winter sample). Activity is expressed as nmol 1-1-P produced per mg protein per h. C, determination of $K_{m}$ value for G-6-P of E. intestinalis (winter sample) plastidial MIPS by non-linear regression kinetics. Activity is expressed as nmol 1-1-P produced per mg protein per h. D, determination of $K_{m}$ value for NAD of E. intestinalis (winter sample) plastidial MIPS by non-linear regression kinetics .Activity is expressed as nmol 1-1-P produced per mg protein per h.

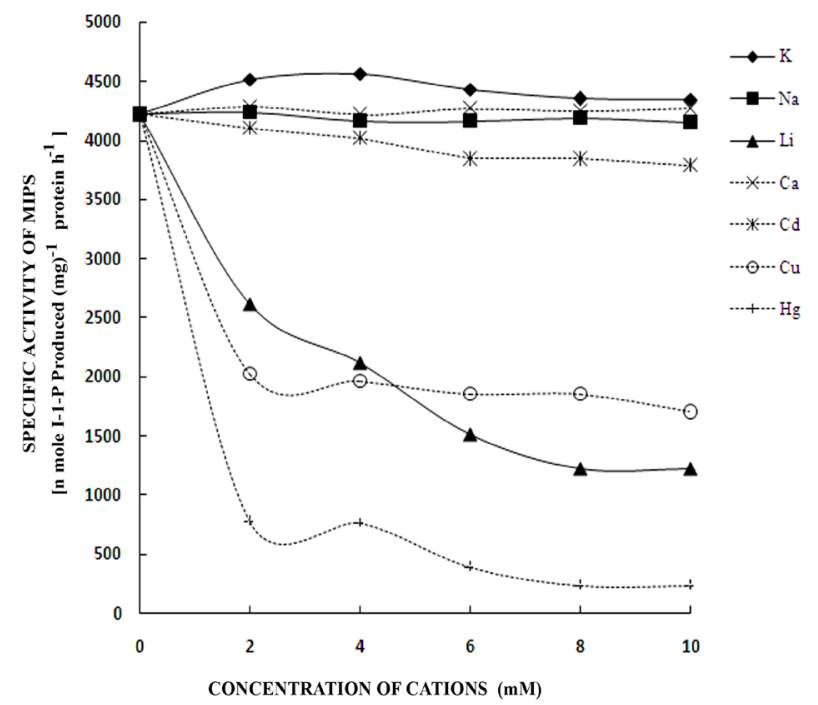

Fig. 4. Effect of monovalent and divalent cations on plastidial L-myo-inositol-1-phosphate synthase activity in Enteromorpha intestinalis (winter sample). Activity is expressed as nmol 1-1-P produced per mg protein per $\mathrm{h}$. metabolic potential and salt stress, brought about by the fluctuations in the lagoon water salinity in a defined macrophyte.

As inositol is one of the important osmoprotectants that can protect cells from the derogatory effects of osmotic imbalance imposed by high salinity levels, higher activity of MIPS along with higher level of free inositol detected in the thalli of $E$. intestinalis collected during winter season seems logical. Since algae are inhabitants of biotopes characterized by changing salinities they have attracted considerable attention in the last two decades and can serve as model organisms for understanding the salt acclimation phenomenon better than in higher plants (Bohnert, Jensen 1996; Bohnert, Sheveleva 1998; Fogg 2001). Salinity is considered as one of the major constraints on species diversity and productivity of algal populations (Booth, Beardall 1991; Chen, Plant 1999). The present work may promote search for better understanding of such correlation, i.e., the level of salinity stress and biosynthesis of other relevant osmo-protectant molecules, particularly in marine macrophytes. 


\section{Acknowledgements}

The authors are grateful to the University Grants Commission, Govt. of India, New Delhi, India for financial assistance [Project No: F-33-189/2007 (SR)] and to Dr. S. Dutta (WBSES), Principal, Barasat Govt. College for his continuous help and encouragement.

\section{References}

Adhikari J., Majumder A.L. 1983. Differences in thermal stability of the foetal and adult brain myo-inositol-1-phosphate synthase: Probable involvement of NAD. FEBS Lett. 163: 46-49.

Adhikari J., Majumder A.L., Bhaduri T.J., Das Gupta S., Majumder A.L. 1987. Chloroplast as a locale of L-myo-inositol-1phosphate synthase. Plant. Physiol. 85: 611-614.

Ashraf M., Foolad M.R. 2007. Roles of glycine betaine and proline in improving plant abiotic stress resistance. Environ. Exp. Bot. 59: 206-216.

Barnett J.E.G., Brice R.E., Corina D.L. 1970. A colorimetric determination of inositol monophosphates as an assay for D-glucose-6-phosphate-1L-myo-inositoL-1-phosphate cyclase. Biochem. J. 119: 183-186.

Basak A., Jha T.B., Adhikari J. 2012. Biosynthesis of myo-inositol in lycopods: characteristics of the pteridophytic 1-myoinositol-1-phosphate synthase and myo-inositol-1-phosphate phosphatase from the strobili of Lycopodium clavatum and Selaginella monospora. Acta Physiol. Plant. 34: 1579-1582.

Bohnert H. J., Nelson D. E., Jensen R. G. 1995. Adaptations to environmental stresses. Plant Cell 7: 1099-1111.

Bohnert H.J., Jensen R.G. 1996. Strategies for engineering waterstress tolerance in plants. Trends Biotechnol. 14: 89-97.

Bohnert H.J., Sheveleva E. 1998. Plant stress adaptations - making metabolism move. Curr. Opin. Plant Biol. 1: 267-274.

Bollag D.M., Rozycki M.D., Edelstein S.J. 1996. Protein Methods. 2nd Ed. Wiley-Liss, New York.

Booth W.A., Beardall J. 1991. Effect of salinity on inorganic carbon utilization and carbonic anhydrase activity in the halotolerant alga Dunaliella salina (Chlorophyta). Phycologia 30: 220-225.

Bradford M.M. 1976. A rapid and sensitive method for the quantitation of microgram quantities of proteins utilizing principle of protein-dye binding. Anal. Biochem. 72: 248-254.

Charalampous F., Chen I.W. 1966. Inositol-1-phosphate synthase and inositol-1-phosphatase from yeast. Meth. Enzymol. 9: 698-704.

Chen R.S., Toribara T.Y., Warner H. 1956. Microdetermination of phosphorous. Anal. Biochem. 28: 1756-1758.

Chen C.S., Plant A.L. 1999. Salt induced protein synthesis in tomato roots. J. Exp. Bot. 50: 677-687.

Chettri D.R., Choudhuri M., Mukherjee A.K., Adhikari J. 2005. L-myo-inositol-1-phosphate synthase: partial purification and characterisation from Gleichenia glauca. Biol. Plant. 49: 59-63.

Chhetri D.R., Mukherjee A.K., Adhikari J. 2006a. Myo-inositol content in pteridophytes and the isolation and characterization of L-myo-inositol-1-phosphate synthase from Diplopterygium glaucum. Braz. J. Plant Physiol. 18: 291-298.

Chhetri D.R., Mukherjee A.K., Adhikari J. 2006b. Partial purification and characterization of L-myo-inositol-1phosphate synthase of pteridophytic origin. Acta Physiol. Plant. 28: 101-107.

Chhetri D.R., Yonzone S., Tamang S., Mukherjee A.K. 2009. L-myoInositoL-1-phosphate synthase from bryophytes: purification and characterization of the enzyme from Lunularia cruciata
(L.) Dum. Braz. J. Plant Physiol. 21: 243-250.

Das-Chatterjee A., Goswami L., Maitra S., Dastidar K.G., Ray S., Majumder A.L. 2006. Introgression of a novel salt-tolerant L-myo-inositol 1-phosphate synthase from Porteresia coarctata (Roxb.) Tateoka (PcINO1) confers salt tolerance to evolutionary diverse organisms. FEBS Lett. 580: 3980-3988.

Dasgupta S., Adhikari J., Majumdar A.L. 1984. Myo-inositol-1phosphate synthase from lower plant groups: purification and properties of the enzyme from Euglena gracilis. Physiol. Plant. 61: 412-416.

Donahue T.F., Henry S.A. 1981a. myo-Inositol-1-phosphate synthase. Characteristics of the enzyme and identification of its structural gene in yeast. J. Biol. Chem. 256: 7077-7085.

Donahue T.F., Henry S.A. 1981b. Inositol mutants of Saccharomyces cerevisiae: mapping the ino1 locus and characterizing alleles of the ino1, ino2 and ino4 loci. Genetics 98: 491-503.

Eisenberg F Jr. 1967. D-myo-inositol 1-phosphate as product of cyclization of glucose 6-phosphate and substrate for a specific phosphatase in rat testis. J. Biol.Chem. 242: 1375-1382.

Fogg G. 2001. Algal adaptation to stress - some general remarks. In: Rai L.C., Gaur J. (eds) Algal Adaptation to Environmental Stresses. Physiological, Biochemical and Molecular Mechanisms. Springer, Berlin. pp. 1-20.

Gaitonde M.K., Griffiths M. 1966. A spectrophotometric method for the determination of microquantities of free inositol in biological material. Anal. Biochem. 15: 532-535.

Gill S.S., Gill R., Anjum N.A. 2014. Target osmoprotectants for abiotic stress tolerance in crop plants-glycine betaine and proline. In: Anjum N A., Gill S.S., Gill R. (eds) Plant Adaptation to Environmental Change: Significance of Amino Acids and their Derivatives. CT:CAB International, Wallingford, pp. 97-108.

Hachtel W. 1976. Sites of synthesis of chloroplast membrances in Vicia faba. In: Bucher T.H., Neupert W., Sebald W., Warner S. (eds) Genetics and Biogenesis of Chloroplasts and Mitochondria. Elsevier/North Holland Biomedical Press, Amsterdam, pp. 49-56.

Joshi R., Ramanarao M.V., Baisakh N. 2013. Arabidopsis plants constitutively overexpressing a myo-inositol 1-phosphate synthase gene (SaINO1) from the halophyte smooth cordgrass exhibits enhanced level of tolerance to salt stress. Plant Physiol. Biochem. 65: 61-66.

Lohia A., Hait N.C., Majumder A.L. 1999. L-myo-Inositol 1-phosphate synthase from Entamoeba histolytica. Mol. Biochem. Parasitol. 98: 67-79.

Loewus F.A., Loewus M.W., Maity I.B., Rosenfield C.L. 1978. Aspects of myo-inositol metabolism and biosynthesis in higher plants. In: Wells W.W., Eisenberg F.Jr. (eds) Cyclitols and Phosphoinositides. Academic Press, New York, pp. 249-267

Maeda T., Eisenberg F. 1980. Purification, structure, and catalytic properties of L-myo-inositol-1-phosphate synthase from rat testis. J. Biol. Chem. 255: 8458-8464.

Majumder A.L., Biswas B.B. 2006. Biology of Inositols and Phosphoinositides. Springer Science \& Business Media.

Rath J., Adhikary S.P. 2005. Distribution of marine macro-algae at different salinity gradients in Chilika lake, east coast of India. Ind. J. Marine Sci. 34: 237-241.

Ray Chaudhuri A., Majumder A.L. 1996. Salinity-induced enhancement of L-myo-nositol 1-phosphate synthase in rice (Oryza sativa L.). Plant Cell Environ. 19: 1437-1442.

Ray Chaudhuri A., Hait N.C., DasGupta S., Bhaduri T.J., Deb R., Majumder A.L. 1997. L-myo-lnositol 1-phosphate synthase 
from plant sources (characteristics of the chloroplastic and cytosolic enzymes). Plant Physiol. 115: 727-736.

Shen B., Hohmann S., Jensen R.G., Bohnert H.J. 1999. Roles of sugar alcohols in osmotic stress adaptation. Replacement of glycerol by mannitol and sorbitol in yeast. Plant Physiol. 121: $45-52$.

Suo J., Zhao Q., David L., Chen S., Dai S. 2017. Salinity response in chloroplasts: Insights from gene characterization. Int. J. Mol. Sci. 18: 1011.

Trevelyan W.E., Proctor D.P., Harrison J.S.1950. Detection of sugars on paper chromatograms. Nature 166: 444-445.

Tuteja N. 2007. Mechanisms of high salinity tolerance in plants. Meth. Enzymol. 428: 419-438. 